\author{
I. М. Демчук, аспірант, \\ e-mail: ivannademcuk19@gmail.com \\ Г. С. Столяренко, д.т.н., професор \\ e-mail: radikal@ukr.net \\ Черкаський державний технологічний університет \\ б-р Шевченка, 460, м. Черкаси, 18006, Україна
}

\title{
АНАЛІЗ ПАРАМЕТРИЧНОЇ СТОХАСТИЧНОЇ СИСТЕМИ СИНТЕЗУ ГІДРАЗИН-СИРЦЮ 3 ВТОРИННОЇ СИРОВИНИ В ХВИЛЬОВОМУ РЕАКТОРІ
}

В роботі розглянуто процес синтезу гідразин-сирию в хвильовому реакторі з точки зору математичного моделювання. Синтез гідразину є основною стадією процесу синтезу гідразину сульфату з вторинної сировини - конденсату сокової пари, утвореної в результаті роботи агрегату синтезу карбаміду. Проведено техніко-економічний аналіз існуючих способів синтезу гідразину та його похідних з різної сировини. Встановлено доцільність продовження дослідження процесу синтезу гідразину з вторинної сировини та підтверджено актуальність теми утилізації конденсатів сокової пари шляхом переробки в гідразин сульфат. Ідентифіковано процес синтезу гідразин-сирию як складний параметричний стохастичний процес. Вивчено фактори впливу на процес синтезу гідразин-сирию, які відповідають умовам пращездатності системи синтезу гідразину з конденсатів сокової пари виробництва карбаміду. Запропоновано методи планування експерименту та встановлено оптимально можливий вектор проведення експерименту в напрямку проведення пасивного експерименту.

Ключові слова: гідразин, конденсат сокової пари, стохастична система, хвильовий реактор, фактор впливу.

Вступ. У статті «Утилізація зв’язаного азоту шляхом переробки в гідразин сульфат у виробничих стічних водах» розглянуто та доведено можливість використання відходу виробництва карбаміду - конденсату сокової пари - до стадії десорбції та гідролізу як сировини для синтезу гідразину як основного напівпродукту в процесі синтезу гідразин сульфату [1]. Як правило, стічні води виробництва карбаміду, які в своєму складі містять низькоконцентровані розчини амонійного та амідного азоту з масовою концентрацією аміаку до $5 \%$, карбаміду до $3 \%$ та 3 невисоким вмістом біурету (до 0,5\% масових), піддають двоступеневій десорбції та гідролізу. На цю стадію витрачається велика кількість пари. Згідно з попередніми розрахунками [2] відсоток заощадження від загальної собівартості готового продукту (карбаміду) для агрегату синтезу за проектом фірми «Уреа Казале» продуктивністю 1000 т/добу при впровадженні утилізаційної технології синтезу гідразин сульфату, за умови ліквідації стадії десорбції та гідролізу, становитиме $1,5 \%$.

Основна частина стічної води після десорбції та гідролізу з масовою концентрацією карбаміду, не більшою ніж 300 мг/дм³ ${ }^{3}$ i масо- вою концентрацією аміаку, не більшою ніж 100 мг/дм ${ }^{3}$, надходить на доочищення в установки нітри-денітрифікації (НДФ). Як відомо, ефективність очищення стоків на установках НДФ від амонійного азоту в середньому по Україні становить близько $77 \%$ при середній концентрації амонійного азоту на вході на рівні 30 мг/дм ${ }^{3}$. Тобто, перед подачею стічних вод виробництва карбаміду після стадії десорбції та гідролізу на установки НДФ їх необхідно додатково розбавити побутовими стоками в десять разів. Крім цього, необхідно забезпечити оптимальні умови функціонування установок НДФ, що на практиці є досить складним та енергоємним процесом. Згідно зі статистичними даними щороку в поверхневі водні об'єкти України потрапляє близько 20 тис. тонн зв'язаного азоту [3]. Що стосується відсотка заощадження на собівартості карбаміду за статтями витрат «Перекачування стоків на установки НДФ» та «Очищення стоків на установках НДФ», то він становить близько $1 \%$ для агрегату синтезу карбаміду продуктивністю 1000 т/добу [2].

Отже, розробка альтернативної утилізаційної технології сприятиме зменшенню собівартості карбаміду в середньому на 2,2-2,5 \% 
(залежно від конструкції агрегату синтезу карбаміду, його продуктивності та вартості енергоресурсів). Тому питання реутилізаціі конденсатів сокової пари виробництва карбаміду є актуальним хоча б з точки зору позитивного економічного ефекту на роботу агрегату синтезу карбаміду.

Що стосується запропонованого в попередніх роботах $[1,2]$ методу синтезу гідразин сульфату 3 вторинної сировини в хвильовому реакторі, то, однозначно, можна підтвердити актуальність продовження проведення досліджень цього методу, тому що, крім позитивного економічного ефекту для агрегату синтезу карбаміду, розробка технології синтезу гідразин сульфату 3 вторинної сировини (низькоконцентрованої водної суміші амідного та амонійного азоту) дасть можливість знизити собівартість гідразин сульфату, позитивно вплине на екосистему за рахунок зменшення навантаження на установки НДФ та сприятиме поглибленню знань в такій галузі наук, як квантова хімія, що точніше описує процеси гомолізу, які відбуваються в хвильовому реакторі.

Постановка проблеми. В зв'язку з тим, що процес синтезу гідразину відбувається в хвильовому реакторі (ескіз лабораторної установки отримання гідразин сульфату зображено в роботі [1]), розглядати процес синтезу гідразину з точки зору елементарної хімії недоречно, тому що під дією електромагнітних хвиль відбуваються паралельно і атомнорадикальні процеси. На жаль, дослідити експериментально вплив мікрохвильового опромінення на кінетику магнітного моменту запропонованого методу синтезу гідразинсирцю досить складно. Саме тому запропонований метод синтезу гідразин сульфату [1], основна стадія якого - синтез гідразин-сирцю, $\epsilon$ досить складною стохастичною системою.

Аналіз останніх досліджень і публікацій. Історія синтезу гідразину почалася 3 1875 року, коли його органічні похідні були відкриті Фішером. Далі синтезувати гідразину гідрат та його неорганічні солі (гідразину сульфат та гідразину хлорит) вдалося Куріусу в 1887 році [4]. Що стосується промислових схем синтезу гідразину, то основною сировиною синтезу гідразину та його похідних на сьогоднішній день $є$ аміак за методом Рашига, карбамід за методом Хофмана, ацетон та перекис водню за методом Юджина-Кульмана [1]. Також було розроблено синтез гідразин сульфату, де як сировина використовується бензохіноназин. Гідразин сульфат утворюється шляхом гідролізу бензохіноназину в присутності розведеної сірчаної кислоти. Ця процедура є дуже складною і вимагає випарювання великої кількості води та вилучення бензохінону шляхом випарювання ефірних сполук, що утворюються при взаємодії бензохінону 3 етиловим ефіром. Це значно ускладнює процес синтезу, тому що концентрація гідразин сульфату в розчині коливається в межах 1$2 \%$ масових [5]. Також розроблено технологію синтезу гідразину сульфату та гідразину гідрату 3 використанням кетонів, котрі зв'язують новоутворений гідразин в діазоциклопропан, який зв' язують сірчаною кислотою, що приводить до утворення гідразину сульфату та кетазину (кетазиновий метод) [4].

Метод Рашига є дешевшим, ніж метод Хофмана, але через пагубний вплив на навколишнє середовище та високе споживання енергоресурсів перевагу віддають методу Хофмана [6]. Деякі агрегати синтезу гідразину за методом Хофмана, побудовані наприкінці минулого століття в таких країнах, як: Німеччина, США, Англія та Японія, збереглися і до нашого часу.

Що стосується синтезу гідразину за методом Юджина-Кульмана, то він може бути економічним, порівнюючи з синтезом Рашига, але все залежить від середньої ринкової вартості на сировину на момент виробництва [6].

Кетазиновий метод має значні переваги, тому що при виробництві кетазину можна уникнути розкладання гідразину, але він $\epsilon$ більш енергозатратним. Цей спосіб синтезу гідразину застосовують здебільшого у Франціï [6].

Гідразин та його солі мають широкий спектр використання. Зокрема, гідразин сірчанокислий використовується: в неорганічній хіміі; в аналітиці; фармакології (використовується в медицині як протипухлинний засіб); у водопідготовці (для обробки підживлювальної води барабанних парогенераторів); в сільському господарстві як один зі складових компонентів пестицидів та бактерицидів; як везикант для виробництва пластику і гуми [7, $8,9]$.

Гідразин сульфат - сильний відновник, набагато стійкіший, ніж гідразин. За умови отримання низькоконцентрованих розчинів гідразин-сирцю 3 вторинної сировини питанню стабілізації гідразину надавалося велике значення. 
Використання таких методів концентрування гідразину, як вакуум-випарювання та виморожування розчинів, є недоречним. При концентруванні гідразину за допомогою вакуум-випарних апаратів втрачається близько $25 \%$ новоутвореного гідразину [10]. За умови низьких концентрацій гідразин-сирцю цей процес $є$ занадто енергоємним. Що стосується виморожування, то цей процес також $є$ занадто енергоємним, до того ж, перебіг процесу виморожування гідразину ускладнюється умовою повної ізоляції системи, що обумовлено швидким окисненням новоутвореного гідразину киснем 3 повітря. Найбільш ефективним способом швидкої стабілізації утвореного в процесі синтезу гідразин-сирцю $є$ переведення його в малорозчинну сіль - гідразину сульфат.

Алгоритму розрахунку параметрів цієї стохастичної системи синтезу гідразину 3 відходів виробництва карбаміду не існує, тому що запропонований метод до цього часу не розглядався.

Мета роботи - проаналізувати параметричну стохастичну систему синтезу гідразинсирцю з конденсатів сокової пари виробництва карбаміду в хвильовому реакторі та визначити фактори впливу на двофазну багатокомпонентну систему синтезу гідразину, які б відповідали умовам працездатності системи.

Виклад основного матеріалу дослідження. Основні та побічні рівняння реакції синтезу гідразину, з точки зору елементарної хімії, без урахування перебігу атомнорадикальних процесів у реакторі синтезу гідразину, представлені у попередніх дослідженнях процесу утилізації зв'язаного азоту шляхом переробки в гідразин сульфат у виробничих стічних водах [1].

Як відомо, в стохастичних системах попередити хід перебігу процесу неможливо, тому що він залежить від випадкових факторів впливу [11].

У цьому процесі випадковими факторами впливу на систему є розподіл хвиль у зоні реакції, градієнт концентрації основних компонентів синтезу гідразину та наявність інгібіторів процесу, а саме розчинених металів у конденсаті сокової пари, та початкова температура вторинної сировини, за умови проекції методу синтезу гідразин сульфату на виробничі масштаби, з прив'язкою до агрегату синтезу карбаміду. Всі ці параметри є однозначно змінними, вони залежать від параметрів перебігу процесу концентрування карбаміду у вакуум-випарних апаратах і процесів розподілу та довжини електромагнітних хвиль у реакторі синтезу.

Всі процеси функціонування реальних складних систем, таких як синтез у парорідинному потоці під дією електромагнітного опромінення, по суті, мають випадковий характер, завдяки чому в моменти надходження вхідних сигналів відбувається регенерація випадкового процесу. Тобто, розвиток процесів у таких системах після надходження вхідних сигналів не залежить від передісторії.

Будь-яку складну технічну систему можна подати як систему $3 \mathrm{n}$ вхідними параметрами $\mathrm{xi}$, де $\mathrm{i}=1,2, \ldots, \mathrm{n}$, та m вихідними параметрами $\mathrm{Yi}$, де $\mathrm{i}=1,2, \ldots, \mathrm{m}$. Тоді система характеризується вектором вхідних $\mathrm{x}=(\mathrm{x} 1$, $\mathrm{x} 2, \ldots, \mathrm{xn}) \mathrm{T}$ та вектором вихідних $\mathrm{Y}=(\mathrm{Y} 1$, Y2, ..., Ym) T параметрів [12].

Створення будь-якої нової технології, машини, механізму та інших систем і процесів починається з визначення технічних умов на вихідні параметри, які називають умовами працездатності. Ці умови виражаються у вигляді номінальних значень вихідних параметрів $\mathrm{Y0}=(\mathrm{Y} 01, \mathrm{Y} 02, \ldots, \mathrm{Y0m}) \mathrm{T}$ і допусків на їх значення як:

$$
\begin{aligned}
& \mathrm{Y} 0 \mathrm{i}-\delta \mathrm{i} \leq \mathrm{Y} 0 \mathrm{i} \leq \mathrm{Y} 0 \mathrm{i}+\delta \mathrm{i}, \mathrm{i}=1,2, \ldots, \mathrm{m}, \\
& \text { або лише як нерівності типу: }
\end{aligned}
$$

$$
\text { [yi }] \leq \mathrm{Yi} \leq \text { [Yi }], \mathrm{i}=1,2, \ldots, \mathrm{m} .
$$

Умови працездатності утворюють область допустимих значень Dу, геометричним відображенням якої у прямокутній декартовій системі координат простору вихідних параметрів Rm $\epsilon$ ортогональний паралелепіпед допусків Dy [12]:

$$
\begin{gathered}
\text { Dy }=\{y \in R m \mid[y i] \leq Y i \leq[Y i], i= \\
=1,2, \ldots, m\} .
\end{gathered}
$$

Часто обмеження встановлюються і на вхідні параметри системи, наприклад, типу:

$$
[\mathrm{xi}] \leq \mathrm{Xi} \leq[\mathrm{Xi}], \mathrm{i}=1,2, \ldots, \mathrm{n} .
$$

В цьому випадку обмеження на вхідні параметри системи встановлюються лише на такий вхідний фізичний параметр, як швидкість потоку реакційної суміші. Інші вхідні параметри системи синтезу гідразину в умовах синтезу з вторинної сировини будуть незалежно змінними. Також встановлюються обмеження на такий параметр, як сталість співвідношення основних компонентів у су- 
міші. За умови перебігу безперервного процесу синтезу гідразин-сирцю, що обумовлений проекцією лабораторної установки синтезу гідразину сульфату на виробничі потужності, цей параметр утримати сталим досить складно навіть при повній автоматизації виробництва, тому, в цьому випадку також буде встановлено обмеження на цей вхідний параметр системи.

Перед нами стоїть основна задача - обгрунтувати запропонований метод утилізації конденсатів сокової пари, щоб його вихідні параметри відповідали умовам працездатності, для забезпечення необхідного рівня якості функціонування методу синтезу гідразинсирцю з конденсатів сокової пари виробництва карбаміду. Інакше кажучи, необхідно знайти область працездатності $\mathrm{Dx}=\{\mathrm{x} \in \mathrm{Rn}\}$, тобто множину точок простору вхідних параметрів досліджуваної системи Rn, в яких виконуються умови працездатності.

Задача побудови області працездатності, вибору номінальних значень вхідних параметрів $\mathrm{x} 0=(\mathrm{x} 01, \mathrm{x} 02, \ldots, \mathrm{x} 0 \mathrm{n}) \mathrm{T}$ i допусків на них називається задачею параметричного синтезу [12].

Для генерування точок простору вхідних параметрів Rn i перевірки їх належності до області працездатності Dx використовують метод Монте-Карло (метод аналізу чутливості та аналізу сценаріїв на базі теорії ймовірностей). Навіть використовуючи найсучасніші комп'ютери, такий підхід викликає значні труднощі через відсутність інформації про закономірності випадкових процесів варіації параметрів і величезний обсяг необхідних при цьому обчислень для розв'язання таких задач зі стохастичними критеріями. Тому на сьогодні розвиток теорії параметричного синтезу ведеться в сторону пошуку методів і алгоритмів зменшення необхідних обчислень, таких як ефективний вибір розміру сітки представлення області працездатності [12].

Задача параметричного синтезу полягає у виборі номінальних вхідних параметрів х0 = $=(\mathrm{x} 01, \mathrm{x} 02, \ldots, \mathrm{x} 0 \mathrm{n}) \mathrm{T}$, які забезпечують максимум імовірності умов працездатності протягом заданого часу:

$$
\mathrm{x} 0=\arg \operatorname{minP}\{\mathrm{X}(\mathrm{x} 0, \mathrm{t}) \in \mathrm{Dx}, \forall \mathrm{t} \in[0, \mathrm{~T}]\},
$$

де $\mathrm{X}(\mathrm{x} 0, \mathrm{t})$ - випадковий процес зміни вхідних параметрів, $\mathrm{t}$ - момент часу, T - максимальна тривалість експлуатації технічної системи.
Труднощі розв'язання задачі (5) полягають у тому, що закони зміни $\mathrm{X}(\mathrm{x} 0, \mathrm{t})$ невідомі, інформація про область Dx $\epsilon$ також невідомою, отже, перевірка $\mathrm{X}(\mathrm{x} 0, \mathrm{t}) \in \mathrm{Dx} \in$ неможливою.

В зв'язку зі складністю генерування точок простору вхідних параметрів Rn i перевірки їх належності до області працездатності Dx використання активного експерименту стає неможливим, тому в цьому випадку потрібно застосовувати пасивний експеримент.

Отже, проведемо ефективний вибір розміру сітки представлення області працездатності для процесу синтезу гідразину з конденсатів сокової пари виробництва карбаміду. Стратегія проведення дослідів визначається зворотним методом оптимізації. При цьому значення цільової функції обчислюють не по моделі, а знаходять безпосередньо з експерименту, виконаного у відповідних умовах. В цьому випадку при плануванні пасивного експерименту в лабораторних умовах можна стабілізувати деякі стохастичні параметри для визначення окремо функції залежності кожного керованого параметра порівняно зі стабілізованими. Далі можна встановити ряд функціональних залежностей для пошуку найкращого корегування області працездатності цільової функції.

Для пошуку найкращого значення цільової функції використовують послідовний симплексний метод, такий як метод ГауссаЗейделя, при якому всі фактори, крім одного, по черзі фіксуються. Рухаючись паралельно одній із осей факторного простору, можна знайти найкраще для розглянутого розрізу поверхні відгуку значення параметра оптимізації. Далі, задаючись оптимальними параметрами одного фактору впливу, необхідно рухатися паралельно наступній осі факторного простору. Послідовне проходження всіх осей факторного простору становить перший цикл дослідження. Процедуру необхідно повторювати до отримання оптимуму. Поширеним недоліком проведення експерименту за цим методом є припинення роботи після виконання першого циклу.

Для оптимізації параметрів синтезу гідразин-сирцю методом Гаусса-Зейделя необхідно провести серію експериментів з трьома умовно стабілізованими факторами впливу на процес. Розберемо питання циклів стабілізації величин в процесі синтезу гідразин-сирцю: 
1. Стабілізація сталості співвідношення вхідних компонентів сировини. Для забезпечення виконання цього параметра в умовах проведення лабораторного експерименту процес синтезу гідразин-сирцю не може бути безперервним, тому що забезпечення сталості кількісного складу стічної води виробництва карбаміду унеможливлюється кінетикою процесу випарювання та конденсування пари.

Використання для синтезу гідразинсирцю модельного розчину унеможливлюється особливими позитивними хімічними параметрами конденсатів сокової пари, а саме - низьким вмістом металів у стоках. Вміст розчинених у конденсаті металів, особливо міді, в рази нижчий, ніж вміст металів у бідистиляті. Як відомо, метали слугують інгібіторами синтезу гідразин-сирцю і при використанні модельного розчину амідного та амонійного азоту на основі бідистиляту необхідно додатково вводити в систему желатин або клей, котрий зв'язує метали, тим самим блокуючи процес окиснення металами новоутвореного гідразину [10].

Після проведення дослідження процесу синтезу гідразин-сирцю з конденсатів сокової пари $з$ введенням в стоки желатину до досягнення масової концентрації в конденсаті $0,1 \%$ вихід гідразин-сирцю знижується в середньому на $20 \%$ масових, що за цих умов суттєво впливає на вихід гідразину та кінцевого продукту - гідразин сульфату.

Для стабілізації мольного співвідношення компонентів необхідно провести розрахунок визначення введеної кількості вхідних речовин в зону реакції та визначити кількість вхідних речовин, що необхідно подати в напірний бак $з$ реакційною сумішшю (1), що зображено на рис. 2 в роботі [1].

2. Стабілізація температури вхідної сировини. Цей фактор впливу на систему застосовується лише при проведенні експерименту в лабораторних умовах, тому що температура конденсатів сокової пари залежить від режиму роботи конденсаторів, і на практиці забезпечити сталість цього параметра досить складно. Але за умови нагальної необхідності можна за допомогою теплообмінної апаратури забезпечити сталість цього параметра навіть при проекції схеми синтезу на виробничі масштаби.

3. Стабілізація швидкості потоку реакційної суміші в реактор синтезу гідразинсирцю. За рахунок вспінення реакційної су- міші в процесі змішування компонентів стабілізувати цей параметр досить складно. До того ж, вся схема синтезу гідразин-сирцю розроблена з виключенням використання насосів, процеси проходять самовільно за рахунок фізичних ефектів, таких як земне тяжіння, різниця температур, капілярний ефект. Ще потрібно враховувати той факт, що в лабораторних умовах досягти турбулентності потоку реакційної суміші за схемою синтезу гідразин-сирцю в хвильовому реакторі неможливо [1]. Звісно, регулювати подачу реакційної суміші в реактор синтезу гідразин-сирцю можна лише частково за допомогою запірної арматури, що розташована перед реактором синтезу гідразин-сирцю. Тому цей фактор впливу в плануванні експерименту є умовно стабілізованим.

Отже, маючи три умовно стабілізовані параметри синтезу, можна провести оптимізацію методом Гаусса-Зейделя. Змінним параметром у цій оптимізації стане основний вихідний параметр - концентрація новоутвореного гідразин-сирцю в реакційній суміші. Цей вихідний параметр прямо пропорційно впливає і на вихід гідразин сульфату в процесі синтезу гідразин сульфату з конденсатів сокової пари виробництва карбаміду, розглянутого в роботі [1].

Висновки. Проведено аналіз параметричної стохастичної системи синтезу гідразин-сирцю з конденсатів сокової пари виробництва карбаміду в хвильовому реакторі, після якого встановлено вектор проведення експерименту в напрямку проведення пасивного експерименту. Вибраний вектор проведення експерименту в напрямку проведення пасивного експерименту обумовлений складністю генерування точок простору вхідних параметрів цієї системи і перевірки їх належності до області працездатності.

Визначено фактори впливу на двофазну багатокомпонентну систему синтезу гідразину, що відповідають умовам працездатності системи, а саме:

- співвідношення вхідних компонентів сировини;

- температура вхідної сировини;

- швидкість потоку реакційної суміші, що надходить у реактор синтезу гідразин-сирцю.

В подальшому планується проведення експериментів зі стабілізацією визначених параметрів 3 метою оптимізації процесу синтезу гідразин-сирцю в хвильовому реакторі 3 конденсатів сокової пари виробництва карбаміду. 


\section{Список літератури}

1. Demchuk I. M. Stolyarenko G. S., Tupytska N. I. Recuperation of bound nitrogen by processing into hydrazine sulfate in industrial wastewater. Вісник Черкаського державного технологічного університету. Серія: Технічні науки. 2016. Вип. 4. C. $114-120$.

2. Демчук I. М., Столяренко Г. С. Економічна оцінка ефективності впровадження технологій вторинної переробки відходів виробництв на прикладі утилізації азотовмісних стоків агрегату синтезу карбаміду. Збірник наукових праць Черкаського державного технологічного університету. Серія: Економічні науки. Черкаси: ЧДТУ, 2017. Вип. 48. С. 37-44.

3. Національна доповідь про стан навколишнього природного середовища в Україні у 2014 році. М-во екології та природних ресурсів України. Київ, 2016. С. 52-96.

4. Коровин Н. В. Гидразин. Москва: Химия, 1980. $272 \mathrm{c}$.

5. Process for producing hydrazine sulfate. Patent № 4239741. Tomiya Isshiki, Tetsuo Tomita, Toshiaki Kozaki, Osamu Aoki, Mitsuo Abe, Norio Takeda, Mitsuo Miura, Yoshiyuki Aoki, Takao Kondo, Kaoru Tsuyuki. USA. Date 16.11.1980.

6. Current technology for the production of hydrazine hydrate. TongJiu Hydrazine Hydrate Industry Co., Ltd. News. 2008. URL: http://ru.hydrazine-hydrate.org/profile /News131030.html (11.05.2018).

7. Куценко С. А., Бутомо Н. В., Гребенюк А. Н. Военная токсикология, радиобиология и медицинская защита СанктПетербург: Фолиант, 2004. 525 с.

8. Богданов Н. А. Вопросы токсикологии ракетного топлива. Ленинград: Изд-во ВМА им. С. М. Кирова, 1961. 132 с.

9. Абдурахманов Э. И., Саттарова М. Д. Полупроводниковый сенсор гидразина. Вестник науки и образования. Серия: Научно-методический журнал. 2015. Вып. 2. С. 9-13.

10. Audrieth L. F., Ogg B. A. The chemistry of hydrazine. New York: Research Associate University of Illinois, 1951. $237 \mathrm{p}$.

11. Воронов А. А., Ким Д. П., Лохин В. М. Теория автоматического управления: учеб. для вузов по спец. «Автоматика и телемеханика». Москва: Высш. шк., 1986. $504 \mathrm{c}$.

12. Горошко А. В., Ройзман В. П. Параметричний синтез допусків як множинна обернена задача забезпечення працездатності складних технічних систем. 2014. URL: https://www.researchgate.net/ publication/281783876_PARAMETRICNIJ _SINTEZ_DOPUSKIV_AK_MNOZINNA_ OBERNENA_ZADACA_ZABEZPECENN A PRACEZDATNOSTI_SKLADNIH TE HNICNIH_SISTEM (10.05.2018).

\section{References}

1. Demchuk, I. M., Stolyarenko, G. S., Tupytska N. I. (2016) Recuperation of bound nitrogen by processing into hydrazine sulfate in industrial wastewater. Visnyk Cherkaskogo derzhavnogo tehnologichnogo universitetu. Seria: Tehnichni nauky, (4), pp. 114-120.

2. Demchuk, I. M., Stolyarenko, G. S. (2017) Economic evaluation of the efficiency of the introduction of technologies for the recycling of industrial wastes on the example of utilization of nitrogen-containing effluent of carbamide synthesis. Zbirnyk naukovykh prats Cherkaskogo derzhavnogo tehnologichnogo universitetu. Seria: Economichni nauky, (48), Cherkasy: ChDTU, pp. 37-44 [in Ukrainian].

3. National report on the state of natural environment in Ukraine in 2014 (2016). Ministry of ecology and natural resources of Ukraine. Kyiv, pp. 52-96 [in Ukrainian].

4. Korovin, N. V. (1980) Hydrasine. Moscow: Khimiya, 272 p. [in Russian].

5. Process for producing hydrazine sulfate. Patent № 4239741. Tomiya Isshiki, Tetsuo Tomita, Toshiaki Kozaki, Osamu Aoki, Mitsuo Abe, Norio Takeda, Mitsuo Miura, Yoshiyuki Aoki, Takao Kondo, Kaoru Tsuyuki, USA. Date 16.11.1980.

6. Current technology for the production of hydrazine hydrate (2008). TongJiu Hydrazine Hydrate Industry Co., Ltd. News. URL: http://ru.hydrazine-hydrate.org/ profile/News131030.html (11.05.2018).

7. Kutsenko, S. A., Butomo, N. V., Hrebeniuk A. N. (2004) Military toxicology, radiobiology and medical protection. St. Petersburg: Foliant, 525 p. [in Russian]. 
8. Bogdanov, N. A. (1961) Issues of toxicology of rocket fuel. Leningrad: Izd-vo VMA im. S. M. Kirova, 132 p. [in Russian].

9. Abdurakhmanov, E. Y. Sattarova, M. D. (2015) Semiconductor sensor of hydrazine. Vestnik nauki i obrazovaniya. Seriya: Nauchno-medodicheskii zhurnal, (2), pp.913 [in Russian].

10. Audrieth, L. F., Ogg, B. A. (1951) The chemistry of hydrazine. New York: Research Associate University of Illinois, 237 p.

11. Voronov, A. A., Kim, D. P., Lokhin, V. M. (1986) Theory of automatic control: text- book for universities on spec. "Automation and telemechanics». Moscow: Vyssh. shkola, 504 p. [in Russian].

12. Goroshko, A. V. Royzman, V. P. (2014) Parametric synthesis of tolerances as a multiple inverse task of ensuring the performance of complex technical systems. URL: https://www.researchgate.net/ publication/281783876_PARAMETRICNIJ _SINTEZ_DOPUSKIV_AK_MNOZINNA_ OBERNENA_ZADACA_ZABEZPECENN A_PRACEZDATNOSTI_SKLADNIH_TE HNICNIH_SISTEM (10.05.2018.

I. M. Demchuk, a graduate student, e-mail: ivannademcuk19@gmail.com

G. S. Stolyarenko, $P h D$, professor e-mail: radikal@ukr.net

Cherkasy State Technological University

Shevchenko blvd, 460, Cherkasy, 18006, Ukraine

\section{ANALYSIS OF PARAMETRIC STOCHASTIC SYSTEM OF THE SYNTHESIS OF HYDRAZINE FROM SECONDARY RAW MATERIALS IN WAVE REACTOR}

In this paper, the synthesis of hydrazine in a wave reactor from the point of view of mathematical modeling is considered. Synthesis of hydrazine is the main stage in the synthesis of hydrazine sulfate from secondary raw materials, namely the condensate of steam formed as a result of carbamide synthesis unit. Existing methods of the synthesis of hydrazine and its derivatives from different raw materials are considered. The relevance of conducting research on the synthesis of hydrazine from secondary raw materials is analyzed. The hydrazine synthesis process has been identified as a complex parametric stochastic process. The factors influencing the process of the synthesis of hydrazine, which correspond to working conditions of the system of hydrazine synthesis from condensates of juice carbamide production steam, are considered. The methods of experiment planning are proposed. An optimally possible vector of conducting an experiment in the direction of a passive experiment is established.

Keywords: hydrazine, steam condensate, stochastic system, wave reactor, factor of influence.

Стаття надійшла до редакиії 28.08.2018.

Статтю представляє Г. С. Столяренко, д.т.н., професор. 